Hum. Genet. 47, 203-205 (1979)

\title{
The Length of the Y Chromosome in Nubian Males and Its Location in Metaphase Spreads
}

\author{
Carlos E. Nasjleti ${ }^{1 *}$, Charles J. Kowalski ${ }^{2}$, James E. Harris ${ }^{2}$, \\ Nadia A. Abu Elsoued ${ }^{3}$, and Mohamed M. Nofal ${ }^{3}$ \\ ${ }^{1}$ Veterans Administration Hospital, 2215 Fuller Road, Ann Arbor, Michigan 48105, USA \\ ${ }^{2}$ University of Michigan, Ann Arbor, Michigan, USA \\ ${ }^{3}$ University of Alexandria, Alexandria, Egypt
}

Summary. A total of 242 metaphase plates from the peripheral blood of Nubian males living near Aswan, Egypt were studied with respect to the length of the $Y$ chromosome and its location in metaphase spreads. The length of the $\mathrm{Y}$ was similar to that found in American Negroes, and the $\mathrm{Y}$ chromosome was peripherally located in 79 of the 242 cells.

\section{Introduction}

Racial variation in the length of the human $Y$ chromosome was demonstrated by Cohen et al. (1966) in a study of Japanese, Asiatic Indians, American Negroes, Jews of Eastern European extraction, and non-Jews of Anglo-Saxon origin. For a good recent review and a comparison of two endogamous Indian groups (Rajputs and Punjabis), see Ghosh and Singh (1975). Cohen et al. (1966) also studied the location of the $\mathrm{Y}$ chromosome in circular metaphase spreads and found the $\mathrm{Y}$ to be peripherally located in 241 of 736 cells ( $32.7 \%$ ). In this paper we study Nubian chromosomes from both these points of view; we relate the length of the Nubian Y chromosome to that of the other ethnic groups and provide results relevant to the location of the $\mathrm{Y}$ chromosome in metaphase spreads.

\section{Materials and Methods}

The present study is based on cells cultured from the peripheral blood of 29 male Nubians from the village of Ballana, near Aswan, in Egypt. Ten cells for karyotyping were obtained from each of these individuals, but technical difficulties rendered several of the preparations unusuable, accounting for our total of but 242 cells. Each of the donors was a normal, healthy Nubian child between 6 and 18 years of age who was participating in a longitudinal study of growth and development in this population. For a general description of this population and a detailed

* To whom offprint requests should be sent 
history of the longitudinal study see Harris et al. (1970). Egyptian Nubia refers to the Nile valley between the first and second cataracts of the Nile river and its people.

The leukocyte cultures were processed following the technique of Moorhead et al. (1960). Our slight modifications to this method have been described elsewhere (Nasjleti et al., 1966). The chromosomes were stained with Giemsa and were banded by the trypsin method of Seabright (1971). For additional details concerning the processing of chromosomes in our laboratory, see Harris et al. (1973) and Kowalski et al. (1976, 1978 a, 1978 b).

The resulting karyotypes were used to obtain the measures $Y_{F}$ and $Y_{2}$ as defined by Cohen et al. (1966). The first of these expresses the length of the $Y$ chromosome relative to the average length of the F-group chromosomes, the latter relative to the average length of the homologous pair of chromosomes 2. We also computed $Y_{G}$, defined analogously to $Y_{F}$, which Cohen et al. (1966) mentioned but did not actually use in their data analysis. Finally, the traditional standardized length of the $Y$ chromosome was calculated: this expresses the length of the $Y$ relative to the sum of the lengths of the haploid autosomal complement of the cell in question (Penrose, 1964).

The location of the $\mathrm{Y}$ chromosome in the metaphase spreads was scored as either peripheral or nonperipheral according to Cohen et al. (1966), who adapted a technique first proposed by Miller et al. (1963). Although we recently developed a standardized method for making this determination whether or not the metaphase is 'circular' (Kowalski et al., 1978b), we employed the Cohen et al. definition so that our results would be comparable to theirs.

\section{Results}

Table 1 gives the mean values of the $Y_{F}$ and $Y_{2}$ indices for the five groups considered by Cohen et al. (1966) and those of our sample of Nubian children. It is seen that, for both $Y_{F}$ and $Y_{2}$, the Nubian mean values are closer to those of American Negroes than to those of any of the other groups.

The mean value for the $Y_{G}$ index in the Nubian sample was 1.7654 and the relative length of the $\mathrm{Y}$ chromosome with respect to the sum of the lengths of the corresponding autosomal complement had a mean value of 0.0245 . This latter figure, expressed as $2.45 \%$, can be compared with $1.96 \%$, computed by Penrose (1964) from data obtained by pooling samples provided by various participants in the Denver and London Conferences.

The location of the $\mathrm{Y}$ chromosome in the metaphase spreads was scored as peripheral in 79 of the 242 cells $(32.6 \%)$ and as nonperipheral in the remaining 163. In terms of percentages, these are virtually identical to the results reported by Cohen et al. (1966).

Table 1. Mean values of $Y_{F}$ and $\mathrm{Y}_{2}$ for six ethnic groups

\begin{tabular}{lll}
\hline & $Y_{F}$ & $Y_{2}$ \\
\hline Japanese & 1.0019 & 0.3252 \\
Jews & 0.9436 & 0.2906 \\
Nubians & 0.9276 & 0.3140 \\
Negroes & 0.9223 & 0.2964 \\
Indians & 0.8842 & 0.2881 \\
Non-Jews & 0.8621 & 0.2670 \\
\hline
\end{tabular}




\section{Discussion}

The length of the $\mathrm{Y}$ chromosome in Nubian males was shown to occupy an intermediate position along the race-specific spectrum of values presented by Cohen et al. (1966). In terms of the indices $Y_{F}$ and $Y_{2}$, the Nubian mean values are most similar to those of American Negroes, perhaps reflecting their common African heritage. These indices also imply that Nubian (and American Negro) $Y$ chromosomes are longer than those of non-Jews of Anglo-Saxon origin. This is also seen upon comparing the relative lengths of the $\mathrm{Y}$ with respect to the haploid autosomal complement obtained in our study and the results given by Penrose (1964). While Penrose's sample was quite heterogeneous (including, e.g., XXY individuals), the bulk of his sample may reasonably be assumed to be Caucasian.

Our results also strongly support those reported by Cohen et al. (1966) concerning the peripheral location of the $\mathrm{Y}$ chromosome. Both studies produced nearly identical proportions of $33 \%$ peripherally located $Y$ chromosomes.

Supported by the Medical Research Service of the Veterans Administration and NIH grant 2R01-DE013013-09A1.

\section{References}

Cohen, M. M., Shaw, M. W., MacCluer, J. W.: Racial differences in the length of the human Y chromosome. Cytogenetics 5, 34-52 (1966)

Ghosh, P. K., Singh, I. P.: Morphological variability of the human chromosomes: in two Indian populations-Rajputs and Punjabis. Humangenetik 29, 67-77 (1975)

Harris, J. E., Ponitz, P. V., Loutfy, M. S.: Orthodontics' contribution to UNESCO's campaign to save the monuments of Nubia: A 1970 field report. Am. J. Orthod. 58, 578-590 (1970)

Harris, J. E., Nasjleti, C. E., Kowalski, C. J.: Discrimination between groups of chromosomes and individual chromosomes in the normal human karyotype. Chromosoma 40, 269-284 (1973)

Kowalski, C. J., Nasjleti, C. E., Harris, J. E.: Human chromosomes: Evidence for autosomal sexual dimorphism. Exp. Cell Res. 100, 56-62 (1976)

Kowalski, C. J., Nasjleti, C. E., Harris, J. E., Walker, G. F.: Chromosome surface area: Further evidence for autosomal sexual dimorphism. Exp. Cell Res. 114, 397-402 (1978a)

Kowalski, C. J., Nasjleti, C. E., Schmitt, B.: On the peripheral location of the Y chromosome. Hum. Genet. 44, 123-135 (1978b)

Miller, O. J., Mukherjee, B. B., Breg, W. R., van Gamble, A.: Non-random distribution of chromosomes in metaphase figures from cultured human leucocytes. I. The peripheral location of the Y chromosome. Cytogenetics 2, 1-14 (1963)

Moorhead, P. S., Nowell, P. C., Mellman, W. J., Battips, D. M., Hungerford, D. A.: Chromosome preparations of leucocytes cultured from human peripheral blood. Exp. Cell Res. 20, $613-616(1960)$

Nasjleti, C. E., Walden, J. M., Spencer, H. H.: Polyploidization and aberration of human chromosomes induced in vitro and in vivo with ionizing radiations. J. Nucl. Med. 7, 159$176(1966)$

Penrose, L. S.: A note on the mean measurements of human chromosomes. Ann. Hum. Genet. 28, 195-196 (1964)

Seabright, M.: A rapid banding technique for human chromosomes. Lancet 1971 II, 971—972 